Неля Самойленко, кандидат історичних наук, дочент кафедри педагогіки ДВНЗ «ПереяславХмельнииький державний педагогічний університет імені Григорія Сковороди».

\author{
Nelia Samoilenko, \\ Ph.D. in History, Associate Professor of the \\ Department of Pedagogy SHEI «Pereiaslav- \\ Khmelnytskyi Hryhorii Skovoroda State \\ Pedagogical University».
}

E-mail:yaoli@meta.ua

ORCID 0000-0003-1682-8534
Наталія Калюжка,

кандидат педагогічних наук, доцент кафедри педагогіки, теорії та методики початкової освіти

ДВНЗ «Переяслав-Хмельницький

державний педагогічний університет імені Григорія Сковороди».

E-mail: klnatali17@ gmail.com
ORCID 0000-0001-8404-1923

Nataliia Kaliuzhka,

Ph.D. in Pedagogy,

Associate Professor of the Department of Pedagogy, Theory and Methodology of Elementary Education SHEI «Pereiaslav-

Khmelnytskyi Hryhorii Skovoroda State Pedagogical University».

\title{
ТЕХНОЛОГІЇ У РОБОТІ 3 ДІТЬМИ 3 ОСОБЛИВИМИ ОСВІТНІМИ ПОТРЕБАМИ
}

У статті розкрито проблему технологій у роботі з дітьми з особливими освітніми потребами. Виділено дві групи інклюзивних технологій: організаційну і педагогічну. Досліджено, щяо організаційні технології пов'язані з етапами організації інклюзивного процесу: ие технологї проектування $i$ програмування, технології командної взаємодії вчителя та спеціалістів, технології організації структурованого, адаптованого $і$ доступного середовища. Серед педагогічних технологій виділено такі: технології диференційованого навчання та індивідуалізації освітнього процесу; технології корекиії навчальних труднощів, щзо виникають у дітей в освітньому прочесі; технології, спрямовані на формування соціальної компетенції; технології оцінювання досягнень учнів.

Ключові слова: діти з особливими освітніми потребами, інклюзивна освіта, інклюзія, когнітивний розвиток дітей, Нова українська школа, психологічні особливості, психологічний супровід, освітній прочес, інформаційно-комп 'ютерні технологїі, сочіальна адаптація.

The education system in Ukraine is considered as the basis of national and spiritual revival of society, with the main task to educate and upbring future generations of citizens, including people with disabilities who are able to preserve and enhance the values of national culture and civil society, to develop and strengthen independent social and legal state. One of the promising areas of education for children with disabilities is their inclusive education in general secondary education institutions, psychological support for the development and training of these children, their successful social adaptation and inclusion in the life of society.

The article highlights two groups of inclusive technologies: organizational and pedagogical. Organizational technologies are connected with the stages of organizing an inclusive process: these are design and programming technologies, technologies of teamwork between a teacher and specialists, technologies for organizing a structured, adapted and accessible environment.

Among the pedagogical technologies we can identify those that can be successfully used in inclusive practice by a teacher in class: the technologies of differentiated learning and the individualization of the educational process; technologies of correction of educational difficulties encountered among children during the educational process; technologies aimed at the formation of social competence; technologies of appraisal of achievements of students.

Keywords: children with special educational needs, inclusive education, inclusion, cognitive development of children, new Ukrainian school, psychological characteristics, psychological support, educational process, information and computer technologies, social adaptation. 
Постановка проблеми. Система освіти в Україні розглядається як основа національного і духовного відродження суспільства. Її основне завдання полягає у вихованні покоління людей, які здатні оберігати та примножувати цінності національної культури та громадянського суспільства, розвивати і зміцнювати незалежну, соціальну та правову державу як складову європейської та світової спільноти. Сучасною світовою тенденцією $є$ прагнення соціальної адаптації осіб $з$ особливостями психофізичного розвитку. У нашому суспільстві починає формуватися нова культурна й освітня норма - повага до людей з фізичними та інтелектуальними вадами. Згідно зі статутом Організації Об'єднаних Націй, Всесвітньої декларації про права людини, діти-інваліди мають рівні права i можливості з іншими людьми. Прийняті Генеральною асамблеєю ООН Конвенція про права дитини та Декларація про права інвалідів визначили пріоритети в правах дітей $з$ особливими освітніми потребами на освітні, медичні послуги, професійну підготовку та трудову діяльність (за даними Всесвітнього банку - це 10-12 \% населення) [48-я сессия..., 2008: с. 44; Аналитическая записка..., 2010]. У нашій державі впродовж десятиліть існувала освітня політика, яка базувалась на принципах роботи системи закладів загальної середньої освіти для «здорових» дітей та так званих спеціальних шкіл для «дітей з особливими освітніми потребами». Останні мали чітку і диференційовану систему освітніх закладів восьми типів - для кожної категорії дітей, що мають особливості психофізичного розвитку (глухих, слабочуючих, сліпих, слабозорих, дітей з порушеннями опорно-рухової сфери, затримкою психічного розвитку, обмеженими розумовими можливостями, мовленнєвими вадами). Одним із перспективних напрямків реформування спеціальної освіти означених категорій дітей $\epsilon$ ї інклюзивна освіта в закладах загальної середньої освіти.

Аналіз останніх досліджень $\boldsymbol{i}$ публікацій засвідчив, що фахівці різних галузей знань вивчають шляхи, можливості та способи переходу від системи спеціальних навчальних закладів до інклюзивної моделі освіти, яка виправдала себе у багатьох країнах світу. Велику увагу різним аспектам цих проблем приділяли Н. Бастуй, М. Ворон, К. Журавель, А. Колупаєва, В. Козлова, І. Луценко, Ю. Найда, М. Шеремет. Необхідність соціальної, культурної і освітньої інклюзії дітей 3 особливими освітніми потребами підкреслюється в роботах С. Алексєєва, С. Альохіна, Л. Годовнікова, Н. Малофєєва, М. Семаго. Протягом останнього десятиліття вітчизняні науковці, зокрема М. Бондар, Т. Свтухова, І. Іванова, В. Синьова, О. Столяренко, А. Шевчук та інші присвячують свої праці дослідженням проблеми залучення дітей 3 особливими проблемами до навчання в закладах загальної середньої освіти.

Метою статmi є визначення сутності інклюзивної освіти, проведення аналізу проблеми організації інклюзивного навчання у закладах загальної середньої освіти та розкритті технологій у роботі з дітьми з особливими освітніми потребами.

Виклад основного матеріалу. За останні роки в Україні відбувається істотна зміна відношення суспільства до осіб із проблемами здоров'я та особливостями психофізичного розвитку. Стає зрозумілим, що психофізичні порушення не заперечують людської суті, здатності відчувати, переживати, набувати соціального досвіду. Назріла необхідність в розумінні проблем дітей з особливими освітніми потребами, у пошані і визнанні їх прав на освіту, бажанні і готовності включити їх в дитяче співтовариство. Кожній дитині необхідно створити сприятливі умови розвитку, які враховують іiі індивідуальні освітні потреби і здібності. Це допоможе 
звільнити таких дітей від соціальної ізоляції, сприятиме здоровій взаємодії їх 3 іншими дітьми та розвитку позитивного, терпеливого, толерантного, лояльного ставлення до них 3 боку оточуючих. Соціалізація дуже важлива для кожної маленької людини, а особливо для дитини 3 обмеженими можливостями. I саме школа має відіграти важливу роль в процесі адаптації іiі до життя.

Під інклюзією (від «іnclusion»- включення) розуміють залучення дітей 3 особливими освітніми потребами в загальноосвітній простір, пристосування освітнього процесу до потреб усіх учнів, зокрема і таких, що мають особливі освітні потреби. Інклюзивна освіта - це система освітніх послуг, яка грунтується на принципі забезпечення основного права дітей на освіту та права здобувати іiі за місцем проживання, що передбачає навчання дитини 3 особливими освітніми потребами в умовах закладу загальної середньої освіти. Інклюзія - це політика та процес, який дає змогу всім дітям брати участь у всіх програмах та визначається в зусиллях, спрямованих на введення дітей у регулярний освітній простір. Відмінність такого підходу полягає у визнанні того факту, що ми змінюємо суспільство, аби воно враховувало й пристосовувалось до індивідуальних потреб людей, а не навпаки. Концепція інклюзивної освіти відображає одну з головних демократичних ідей - всі діти є цінними й активними членами суспільства.

Виходячи 3 даних Всесвітнього банку, Інститут Юнеско 3 Інформаційних технологій в освіті (IITE) у своїй аналітичній записці за жовтень 2010 р. зазначав, що кількість дітей-інвалідів молодших 16 років оцінюється в 140-165 мільйонів, 62 мільйони - це діти молодшого шкільного віку [Аналитическая записка..., 2010]. В Україні кількість дітей-інвалідів, за даними Уніан, понад 165 тисяч чоловік [Аналитическая записка..., 2010]. В школах для дітей з вадами розвитку в 2008 році навчалось 66661 (шістдесят шість тисяч шістсот шістдесят одна) дитина. Водночас, за офіційними даними, «на березень 2010 року до закладів загальної середньої освіти було інтегровано 103 тисячі дітей з особливими освітніми потребами, у тому числі 45 тисяч дітей-інвалідів. На 1 березня 2011 року в Україні в закладах загальної середньої освіти створено близько 536 спеціальних класів, які охоплюють майже 6 тисяч дітей. Ці дані, 3 одного боку, свідчать про достатньо швидкі темпи впровадження інклюзивного навчання в практику закладів загальної середньої освіти України, а 3 другого - про тенденцію не стільки до реалізації справжнього інклюзиву, скільки про механічне переміщення дитини із спеціалізованої школи в спеціалізований клас при закладі загальної середньої освіти. Подібний підхід, всупереч його зовнішній привабливості (адже дитина залишається в сім’і, не відривається від батьківської опіки), все ж не вирішує основного завдання інклюзиву - соціалізацію дитини, повноцінне включення ії в колектив здорових дітей, розвиток здібностей жити в суспільстві, відчувати свою спорідненість із ним. Адже мета інклюзиву - не механічне переведення учня з одного типу навчального закладу до іншого, а спроба такої організації життя дитини, за якої вона навчиться відчувати себе не гіршою за інших, спроможною, попри особливості свого фізичного стану, вільно вибудовувати успішний проект власного життя на основі розуміння своєї соціальної значущості. Результатами інклюзії повинно стати: надання учням можливості постійно й активно брати участь в усіх заходах загальноосвітнього процесу; адаптація до життя в соціумі та подолання стереотипів; індивідуальна допомога, включена в загальний процес навчання таким чином, щоб не відокремлювати і не ізолювати учня [Атаков, 2003; Воронов, 2016; Жаворонков, 2005; Материаль по инклюзивному..., 2008]. Поставлені завдання досить точно 
відображають мету інклюзії - забезпечення дітей з особливими потребами якісним навчанням та всебічним розвитком.

Інклюзія означає розкриття кожного учня за допомогою освітньої програми, яка досить складна, але відповідає його здібностям. Інклюзія враховує потреби, так само як і спеціальні умови, і підтримку, що необхідні учню та вчителям для досягнення успіху. В інклюзивній школі кожного приймають і вважають важливим членом колективу, що надає особливій дитині впевненості в собі і виховує в інших дітях чуйність та розуміння. Учня з особливими потребами підтримують однолітки та інші члени шкільного співтовариства для задоволення його спеціальних освітніх потреб. Більшість дітей 3 відхиленнями в розвитку, всупереч зусиллям сім’ї, спеціалістів, суспільства 3 їх навчання та виховання, коли виростають, залишаються непідготовленими до включення в соціальноекономічне життя. Разом з тим, результати досліджень та практика свідчать про те, що кожна людина, яка має вади у розвитку, може, за відповідних умов, стати повноцінною особистістю, розвиватися духовно, матеріально себе забезпечувати і бути корисною для суспільства [Атаков, 2003; Ворон, 2006; Колупаєва, 2009; Материальл по инклюзивному..., 2008]. В останні роки все більш помітним стає прагнення до змін ситуації, що склалася, стосовно дітей $з$ особливими освітніми потребами. Варто відмітити увагу з боку держави щодо інклюзивного навчання: починаючи 31997 року було прийнято ряд відповідних Постанов КМУ (№ 346 від 14.05.1997 р., № 963 від 14.06.2000 р., № 872 від 15.08.2011 р., № 635 від 18.07.2012 р.), наказів, листів Міністерства освіти і науки, молоді та спорту України (наприклад, накази № 1087 від 01.12.2008 р., № 912 від 01.10.2010 р., лист № 1/9-529 від 26.07.2012 р.), Закон № 6437 про внесення змін до закону України «Про освіту» щодо особливостей доступу осіб з особливими освітніми потребами до освітніх послуг від 23.05.2017 р., Про внесення змін до Закону України «Про освіту» щодо особливостей доступу осіб 3 особливими освітніми потребами до освітніх послуг № 2145-VIII від 05.09.2017 р., Наказ МОН України від 23.04.2018 р. № 414 «Про затвердження типового переліку спеціальних засобів корекції психофізичного розвитку дітей з особливими освітніми потребами, які навчаються в інклюзивних та спеціальних класах закладів загальної середньої освіти», Наказ МОН України від 12.06.2018 р. № 627 «Про затвердження типової освітньої програми спеціальних закладів загальної середньої освіти II ступеня для дітей з особливими освітніми потребами».

Прийнятий у 2017 році Закон України «Про освіту» $є$ новаторським та відкриває широке поле впровадження інклюзії у системі освіти. У жовтні 2017 року Міжнародний фонд «Відродження» та «Благодійний фонд Порошенка» підписали Меморандум про співпрацю в межах Ініціативи з впровадження інклюзивної освіти в Україні.

У 2017 році Міністерство освіти і науки України розробило й затвердило концепцію «Нової української школи», яка передбачає високу мету - вчителі набудуть нових компетентностей, які зроблять школу такою, до якої приємно ходити учням, де прислухаються до їхньої думки, вчать критично мислити, не боятись висловлювати власну думку та бути відповідальними громадянами. В основу концепції покладено педагогіку партнерства: співпраця між учителем, учнем i батьками, які мають стати рівноправними учасниками освітнього процесу.

У Новій українській школі кожен вчитель вмітиме працювати 3 дітьми 3 особливими освітніми потребами. Завдання «розроблення та запровадження обов'язкового курсу для всіх педагогічних працівників щодо особливостей роботи 3 
дітьми 3 особливими освітніми потребами в рамках інклюзивного навчання» включено до Плану заходів на 2017-2029 роки із запровадження «Нової української школи» і вже затверджено розпорядженням Кабміну.

Фонд «Відродження» підтримав ініціативу «Благодійного фонду Порошенка» 3 розробки і впровадження нового курсу 3 інклюзивної освіти для студентів вищих педагогічних навчальних закладів. У рамках спільної ініціативи планується, що курс буде адаптовано для перепідготовки і підвищення кваліфікації вчителів.

Однак проблема виховання та реабілітації дітей 3 вадами розвитку залишається складною. Потрібна розробка нових теоретичних підходів до їх навчання та інтеграції в суспільство. Зауважимо, що в Україні система інклюзії має зовсім маленький досвід. Одне 3 теоретичних осмислень цього підходу міститься у статті О. Понятковської «Такие же как все». Авторка підкреслює значущість інклюзії, говорить про проблеми ії впровадження та про зарубіжний досвід 3 цього питання [Понятковская, 2004: с. 10]. На Заході система інклюзивної освіти знаходиться на більш високому рівні і теоретично розроблена набагато краще. Можна відмітити такі праці, як «Удосконалення освіти» (Improvivg Education. The Promise of Inclusive Schools) Національного Інституту вдосконалення міської освіти США, «Інклюзивна освіта при обмежених ресурсах» (Sue Stubbs. Inclusive Education Where There are few resources, 2002) та ін. Сьогодні існує вже досить багато освітніх закладів, що перейшли на інклюзивну освіту. Але ще залишається багато перепон для реалізації проекту 3 впровадження інклюзивної освіти в заклади загальної середньої освіти. Основні 3 них: різномаїтість категорій дітей 3 особливими освітніми потребами: від незначних порушень, наприклад, слуху - до глибокої затримки у розвитку; психологічний бар'єр - страх перед невідомим, страх шкоди інклюзії для інших учасників процесу, негативні настанови, забобони, небажання змін, психологічна неготовність до роботи 3 «особливими» дітьми; архітектурна недоступність освітніх закладів; діти 3 особливими освітніми потребами часто визнаються нездатними до навчання; більшість вчителів та директорів шкіл недостатньо обізнані 3 проблемами входження дітей 3 особливими освітніми потребами в освітній процес у звичайних класах; батьки дітей 3 особливими освітніми потребами не знають, як відстоювати права своїх дітей на освіту i відчувають страх перед системою освіти та соціальної підтримки. Таким чином, інклюзивна освіта - прогресивний спосіб освіти, який має великі перспективи в сучасному суспільстві. Для реалізації потрібні теоретичні обгрунтування, методи, які ще мають бути створені. Крім того, потрібні спеціалісти, які будуть втілювати цей проект в життя, бо далеко не всі сучасні педагоги здатні перебудуватися на нову систему. Інклюзивна освіта - важливий проект, який потрібно розвивати, вдосконалювати та втілювати в життя, якому потрібна підтримка держави, спеціалістів, батьків і педагогів. На думку багатьох спеціалістів [Атаков, 2003; Воронов, 2016; Жаворонков, 2005; Как нам..., 2008; Колупаєва, 2009; Материаль по инклюзивному..., 2008; Понятковская, 2004; Прихожан, 2010; Coфiü, 2007; Pastor, 2009; Riding, 1991; Rogers, 1993], інклюзивна освіта - новий етап в розвитку освіти взагалі. Адже в державних освітніх закладах часто не враховуються здібності кожної конкретної дитини. Це пов'язано $з$ переповненістю класів, педагоги просто не в змозі шукати підхід до кожного 3 25-35 учнів, а тим більш, коли таких класів декілька. У той же час інклюзивна освіта дає можливість включати в систему освіти дітей-інвалідів, що ставить на новий рівень соціальну підтримку цієї категорії 
громадян. Крім того взаємодія 3 іншими дітьми сприяє когнітивному, фізичному, мовному, соціальному та емоційному розвиткові дітей 3 особливими освітніми потребами. При цьому діти 3 типовим рівнем розвитку демонструють відповідні моделі поведінки дітям 3 особливими освітніми потребами i мотивують їх до розвитку та цілеспрямованого використання нових знань та вмінь. Взаємодія «здорових» дітей і дітей з особливими освітніми потребами в інклюзивних класах сприяє налагодженню між ними дружніх стосунків, сприяє розвиткові емпатії, толерантності, об'єктивній оцінці власних можливостей, формуванню реалістичного світогляду. Базуючись на результатах міжнародних досліджень, досвіді інтегрованого та інклюзивного навчання в нашій державі, - можна стверджувати, що таке навчання корисне не лише для дітей з особливими освітніми потребами, а й для їхніх однолітків, батьків. Воно сприяє розвиткові емпатії, толерантності, об'єктивній оцінці власних можливостей, формуванню реалістичного світогляду. Інклюзія передбачає особистісно орієнтовані методи навчання, в основі яких - індивідуальний підхід до кожної дитини 3 урахуванням усіх іï індивідуальних особливостей (здібностей, особливостей розвитку, типів темпераменту, статі, сімейної культури тощо). Інклюзивне навчання вимагає гнучкої, індивідуалізованої системи навчання дітей 3 особливостями психофізичного розвитку в умовах закладів загальної середньої освіти за місцем проживання. Навчання відбувається за індивідуальним планом, і кожна дитина повинна бути забезпечена медико-соціальним та психологопедагогічним супроводом. Залучення дітей 3 особливостями психофізичного розвитку до закладів загальної середньої освіти передбачає позитивний вплив на широке коло близьких для них людей: батьків, інших членів родини. Входження дитини в коло своїх однолітків може сприяти поступовій зміні і психічного стану їхніх батьків - послаблюватиме напруженість, покращуватиме емоційний стан, підвищуватиме ефективність освітньої корекційної роботи. Активна, мотивована, ціннісно-орієнтована i керована участь батьків в освітньому процесі буде обумовлювати зменшення їхніх тривог і страхів, мобілізовуватиме сили на щоденне і перспективне досягнення успіху, по-новому структуруватиме світосприйняття цілої родини, близьких до неї людей. Інклюзивна освіта - це визнання індивідуальних особливостей кожної дитини, яка передбачає «підстроювання» системи навчання особистість, а не особистість під систему. Переваги отримають усі діти, в інклюзивних класах частіше використовуються нові підходи до навчання, застосовуються варіативні форми, методи і технології виховання.

Під технологіями інклюзивної освіти розуміємо ті технології, які ведуть до створення умов для якісної, доступної освіти всіх без винятку дітей. Можна виділити дві великі групи інклюзивних технологій: організаційну і педагогічну. Організаційні технології пов'язані з етапами організації інклюзивного процесу: це технології проектування i програмування, технології командної взаємодії вчителя та спеціалістів, технології організації структурованого, адаптованого і доступного середовища.

Серед педагогічних технологій можна виділити ті, які можуть бути успішно використані в інклюзивній практиці вчителем на уроці:

1. Технології диференційованого навчання та індивідуалізації освітнього процесу.

2. Технології корекції навчальних труднощів, що виникають у дітей в освітньому процесі.

3. Технології, спрямовані на формування соціальної компетенції. 
4. Технології оцінювання досягнень учнів.

Навчання з урахуванням індивідуальних особливостей учнів повинно бути на кожному уроці. Наприклад, на уроках літературного читання учням, відповідно до рівня їхнього розвитку, пропонуються різновиди переказу: хтось може переказувати «близько до тексту», хтось може розповісти з опорою на картинки, але $\epsilon$ і такі діти, яким переказ зовсім не дається. У цьому випадку вчитель може використовувати ілюстрації-слайди, на яких, поряд 3 малюнком, $є$ текст 3 пропущеними словами. Учень повинен сам згадати їх і вставити в свою розповідь. Після такої роботи багато дітей вже переходять до переказу з опорою на картинки, ну а наступна мета переказ «близько до тексту». На уроках математики диференціація виражається в різнорівневих завданнях, як за складністю, та і за самостійністю їх виконання. Диференційний підхід у навчанні при фронтальних формах організації навчальної діяльності фактично не може бути здійснено. Саме групова та робота «у парах» найкраще допомагає розвитку комунікативних здібностей учнів. Включення дитини 3 особливостями в групову роботу носить поступовий і послідовний характер. Основними критеріями ефективності групової роботи на занятті в інклюзивному класі буде не орієнтація на успіх: «хто більше і краще», а орієнтація на узгодженість, взаємодопомогу, підтримку, спільне прийняття рішень, здатність знаходити компромісне рішення. Ці ж критерії стають головними не лише на уроках, але і на виховних та загальношкільних заходах. Одним з основних технологій інклюзивної освіти є формування навичок потрібних у житті, або соціальної компетенції (навичок взаємодії, взаємодопомоги, продуктивної діяльності і т.д.). Можна виділити 3 типи технологій, спрямованих на підвищення соціальної компетенції: пряме навчання соціальним навичкам; формування соціальних навичок через наслідування, організація групових видів активності, в тому числі і ігрових. Технологія оцінювання досі викликає багато суперечок серед педагогів. Як показує досвід, не завжди вчителі інклюзивного класу звертають увагу на витрачені зусилля дитини під час виконання завдання. Не знаючи, як оцінити роботу - перехвалюють або недооцінюють результати. У цьому випадку учень не розуміє, за якими критеріями оцінювали його роботу. Також ця позиція неминуче викликає нерозуміння серед однокласників «особливої» дитини. Тому дуже важлива взаємодія педагога 3 батьками, фахівцями психолого-педагогічної підтримки. Учитель, психолог, батьки можуть допомогти дитині стати більш компетентним у цьому питанні: заздалегідь ознайомити дитину 3 матеріалом, підготувати наочні посібники, познайомити дитину з критеріями оцінки навчальної діяльності.

Інклюзивна освіта - прогресивний спосіб навчання, який має великі перспективи в сучасному суспільстві, і це дає надію, що кожна дитина з обмеженими можливостями зможе реалізувати право на отримання якісної освіти, адаптованого до його можливостей і потреб, знайти своє місце в житті і реалізувати свій життєвий шанс і потенціал.

Висновки. Однак, досягти визначених цілей інклюзивної освіти без залучень сучасних інформаційно-комп'ютерних технологій практично неможливо. I справа зовсім не у поганій підготовці вчителів до роботи 3 «особливими» дітьми (ця проблема вирішується простим запровадженням спеціальних навчальних дисциплін до програм педагогічних закладів вищої освіти), і не у потребі постійного моніторингу стану здоров'я дітей з обмеженими можливостями - це завдання МОЗ. Головна складність полягає у самій специфіці хворих дітей: вони фізично не здатні постійно перебувати в класі, сидіти на всіх уроках, бути присутніми на всіх 
шкільних заходах. До того ж сам процес навчання має проходити ніби на двох рівнях - пояснення для більшості класу повинне супроводжуватись паралельним уточнюючим навчанням особливої дитини. При цьому всі інші діти не повинні бути «включені» в це додаткове пояснення, оскільки усвідомлення «різності» отримуваної інформації може породжувати відчуття «нерівності» серед однокласників. Досягти подібного можливо лише за умови включення додаткового інформаційного каналу, комп'ютерного зв'язку між учителем і учнем, учнем 3 особливими потребами та однокласниками; створення ефекту присутності дитини на уроці навіть за умови іiі фізичної відсутності в класі. Залучення новітніх інформаційних технологій дозволить вирішити головну проблему інклюзії гармонійне включення особистісно-орієнтованих методів навчання 3 класноурочною системою та реалізацію завдань інтенсивного розвитку когнітивних здібностей дітей-інвалідів, їх соціалізацію.

\section{ЛІТЕРАТУРА}

48-я сессия..., 2008 - 48-я сессия Международной конференции по образованию. Заключительный доклад [Электронный ресурс]. - ЮНЕСКО, 2008. - С. 44. - Режим доступа : http://www.ibe. unesco.org/fi leadmin/user_upload/Policy_Dialogue/48th_ICE/ICE_FINAL_REPORT_rus.pdf

Атаков, 2003 - Акатов Л. И. Социальная реабилитация детей с ограниченными возможностями здоровья. Психологические основы : учеб. пособие для студ. высш. учеб. заведений / Л. И. Акатов. - М. : ВЛАДОС, 2003. - 368 с.

Аналитическая записка.., 2010 - Аналитическая записка Института ЮНЕСКО по информационным технологиям в образовании за октябрь 2010 г. [Электронный ресурс]. - Режим доступа : http://ru.iite.unesco. org/publications/3214675/.

Ворон, 2006 - Ворон М. В. Інклюзивна освіта: українські реалії / М. В. Ворон, Ю. М. Найда. - К. : Плеяди, 2006.

Воронов, 2016 - Воронов А. В. Науково-методическое и кадровое обеспечение развития инклюзивного образования / А. В. Воронов, Т. И. Мороз, С. И. Пугач, Ю. Л. Загуменов // Ресурсные материалы по вопросам инклюзивного образования и образования для устойчивого развития [Электронный ресурс] // Международное бюро просвещения ЮНЕСКО, Сообщество практики по развитию куррикулума в СНГ. - Режим доступа: http://www.ibe.unesco. org/fi leadmin/user_upload/COPs/Pages_documents/Focal_Points/Resource_materials_on_IE_and_ESD.pdf.

Грабовська, 2011 - Грабовська С. Л. Психологічні особливості ставлення учнів загальноосвітньої школи до інклюзивного навчання / С. Л. Грабовська, К. О. Островська // Збірник наукових праць Інституту психології імені Г. С. Костюка Національної АПН України / [За ред. С. Д. Максименка]. - Т. XIII. Част. 5. - К., 2011. - С. 77-85.

Жаворонков, 2005 - Жаворонков Р. Реализация права детей-инвалидов на образование (европейская практика и российский опыт) / Р. Жаворонков // Человек и труд. - 2005. - № 9. - С. 22-28.

Как нам.., 2008 - Как нам планировать инклюзивное образование (ИО)? [Электронный ресурс]. - М. : ГОУ СОШ № 1299, 2008. - Режим доступа : http://school.msk.ort.ru/integration/index. php?p=teor_mpio.

Колупаєва, 2009 - Колупаєва А. А. Інклюзивна освіта: реалії та перспективи : монографія / А. А. Колупаєва. К. : Самміт-Книга, 2009. - С. 5-32.

Кондратенко, 2009 - Кондратенко Л. О. Психологічні особливості інтелектуальної діяльності дитини в кіберпросторі / Л. О. Кондратенко // Актуальні проблеми психології: Психологічна теорія i технологія навчання / [За ред. С. Д. Максименка, М. Л. Смульсон]. - К. : Вид-во НПУ імені М.П. Драгоманова, 2009. - Т. 8. - Вип. 6. - С. 139-146.

Материаль по инклюзивному..., 2008 - Материалы по инклюзивному образованию [Электронный ресурс]. М. : ГОУ СОШ № 1299, 2008. - Режим доступа : http://school.msk.ort.ru/integration/index.php?p=teor_ mріо, свободный.

Понятковская, 2004 - Понятковская О. Такие же как все / О. Понятковская // Социальная защита. - 2004. № 2. - C. 10-13.

Прихожан, 2010 - Прихожан А. М. Влияние электронной информационной среды на развитие личности детей младшего школьного возраста [Электронный ресурс] / А. М. Прихожан // Психологические исследования : электрон. науч. журн. - 2010. - № 1(9). - Режим доступа : http://psystudy.ru.

Смульсон, 2007 - Смульсон М. Л. Проектування середовища дистанційного навчання / М. Л. Смульсон // Тези доповідей науково-практичної конференції «Нові технології навчання: психологічні проблеми» / [За ред. С. Д. Максименка, М. Л. Смульсон]. - Житомир : Вид-во ЖДУ ім. І. Франка, 2007. - С. 40. 
Смульсон, 2009 - Смульсон М. Л. Інтелектуальний саморозвиток у віртуальному освітньому середовищі: зміна парадигми / М.Л. Смульсон // Актуальні проблеми психології: Психологічна теорія i технологія навчання / [За ред. С. Д. Максименка, М. Л. Смульсон]. - К. : Вид-во НПУ імені М.П. Драгоманова, 2009. - Т. 8. - Вип. 6 - С. 250-259.

Софій, 2007 - Софій Н. 3. Концептуальні аспекти інклюзивної освіти / Інклюзивна школа: особливості організації та управління : навчально-методичний посібник / Кол. Авторів : Колупаєва А. А., Найда Ю. М., Софій Н. З. та ін.; [За ред. Л. І. Даниленко]. - К., 2007. - 128 с.

Статистические данные... - Статистические данные на сайте Организации по защите прав ребенка [Электронный ресурс]. - Режим доступа : http:///www.opcr/org/english/stats_world.htm.

Pastor, 2009 - Pastor C. Analysing and federation the European assistive technology ICT industry / C. Pastor et al. // European Commission Information Society and Media. - 2009. - 188 p.

Riding, 1991 - Riding R. J. Cognitive style - an overview and integration / R.J. Riding, I. Cheema // Educat. Psychology. - 1991. - V. 11. - P. 193-215.

Rogers, 1993 - Rogers I. The Inclusion Revolution / I. Rogers. - Bloomington : Phi Delton Kappa, 1993. - 258 p.

World Bank, 2007 - World Bank, 2007. Measuring Disability Prevalence [Электронный ресурс] (Распределение уровня инвалидности. Всемирный Банк, 2007). - Режим доступа: http://siteresources. worldbank.org/DISABILITY/Resources/Data/MontPrevalence.pdf.

\section{REFERENCES}

48-ya sessiya..., 2008 - 48-ya sessiya Mezhdunarodnoy konferentsii po obrazovaniyu. Zaklyuchitelnyiy doklad [Elektronnyiy resurs]. - YuNESKO, 2008. - S. 44. - Rezhim dostupa : http://www.ibe. unesco.org/fi leadmin/user_upload/Policy_Dialogue/48th_ICE/ICE_FINAL_REPORT_rus.pdf

Atakov, 2003 - Akatov L.I. Sotsialnaya reabilitatsiya detey s ogranichennyimi vozmozhnostyami zdorovya. Psihologicheskie osnovyi : ucheb. posobie dlya stud. vyissh. ucheb. zavedeniy / L.I. Akatov. - M. : VLADOS, 2003. - $368 \mathrm{~s}$.

Analiticheskaya zapiska..., 2010 - Analiticheskaya zapiska Instituta YuNESKO po informatsionnyim tehnologiyam v obrazovanii za oktyabr 2010 g. [Elektronnyiy resurs]. - Rezhim dostupa : http://ru.iite.unesco. org/publications/3214675/.

Voron ,2006 - Voron M.V. Inkliuzyvna osvita: ukrainski realii / M.V. Voron, Yu.M. Naida. - K. : Pleiady, 2006.

Voronov, 2016 - Voronov A.V. Naukovo-metodycheskoe y kadrovoe obespechenye razvytyia ynkliuzyvnoho obrazovanyia / A.V. Voronov, T.Y. Moroz, S.Y. Puhach, Yu.L. Zahumenov // Resursnыe materyalы po voprosam ynkliuzyvnoho obrazovanyia y obrazovanyia dlia ustoichyvoho razvytyia [Эlektronnыi resurs] Mezhdunarodnoe biuro prosveshchenyia YuNESKO, Soobshchestvo praktyky po razvytyiu kurrykuluma v SNH, 2016. $\quad-\quad$ Rezhym $\quad$ dostupa: http://www.ibe.unesco. $\quad$ org/fi leadmin/user_upload/COPs/Pages_documents/Focal_Points/Resource_materials_on_IE_and_ESD.pdf.

Hrabovska, 2011 - Hrabovska S.L. Psykholohichni osoblyvosti stavlennia uchniv zahalnoosvitnoi shkoly do inkliuzyvnoho navchannia / S.L. Hrabovska, K.O. Ostrovska // Zbirnyk naukovykh prats Instytutu psykholohii imeni H.S. Kostiuka Natsionalnoi APN Ukrainy / [Za red. S.D. Maksymenka]. - T. KhIII. Chast. 5. - K., 2011. - S. 77-85.

Zhavoronkov, 2005 - Zhavoronkov R. Realizatsiya prava detey-invalidov na obrazovanie (evropeyskaya praktika i rossiyskiy opyit) / R. Zhavoronkov // Chelovek i trud. - 2005. - № 9. - S. 22-28.

Kak nam..., 2008 - Kak nam planirovat inklyuzivnoe obrazovanie (IO)? [Elektronnyiy resurs]. - M. : GOU SOSh \# 1299, 2008. - Rezhim dostupa : http://school.msk.ort.ru/integration/index. php?p=teor_mpio.

Kolupaieva, 2009 - Kolupaieva A.A. Inkliuzyvna osvita: realii ta perspektyvy : monohrafiia / A.A. Kolupaieva. - K. : Sammit-Knyha, 2009. - S. 5-32.

Kondratenko, 2009 - Kondratenko L.O. Psykholohichni osoblyvosti intelektualnoi diialnosti dytyny v kiberprostori / L.O. Kondratenko // Aktualni problemy psykholohii: Psykholohichna teoriia i tekhnolohiia navchannia / [Za red S.D. Maksymenka, M.L. Smulson]. - K. : Vyd-vo NPU imeni M.P. Drahomanova, 2009. - T. 8. Vyp. 6. - S. 139-146.

Materialyi po inklyuzivnomu..., 2008 - Materialyi po inklyuzivnomu obrazovaniyu [Elektronnyiy resurs]. - M. : GOU SOSh \# 1299, 2008. - Rezhim dostupa : http://school.msk.ort.ru/integration/index.php?p=teor_mpio, svobodnyiy.

Ponyatkovskaya, 2004 - Ponyatkovskaya O. Takie zhe kak vse / O. Ponyatkovskaya // Sotsialnaya zaschita. - 2004. № 2. - S. 10-13.

Prihozhan, 2010 - Prihozhan A.M. Vliyanie elektronnoy informatsionnoy sredyi na razvitie lichnosti detey mladshego shkolnogo vozrasta [Elektronnyiy resurs] / A.M. Prihozhan // Psihologicheskie issledovaniya : elektron. nauch. zhurn. - 2010. - № 1(9). - Rezhim dostupa : http://psystudy.ru.

Smulson, 2007 - Smulson M.L. Proektuvannia seredovyshcha dystantsiinoho navchannia / M.L. Smulson // Tezy dopovidei naukovo-praktychnoi konferentsii «Novi tekhnolohii navchannia: psykholohichni problemy» / [Za red. S.D. Maksymenka, M.L. Smulson]. - Zhytomyr : Vyd-vo ZhDU im. I. Franka, 2007. - S. 40.

Smulson, 2009 - Smulson M.L. Intelektualnyi samorozvytok u virtualnomu osvitnomu seredovyshchi: zmina paradyhmy / M.L. Smulson // Aktualni problemy psykholohii: Psykholohichna teoriia i tekhnolohiia 
navchannia / [Za red. S.D. Maksymenka, M.L. Smulson]. - K. : Vyd-vo NPU imeni M.P. Drahomanova, 2009. - T. 8. - Vyp. 6 - S. 250-259.

Sofii, 2007 - Sofii N.Z. Kontseptualni aspekty inkliuzyvnoi osvity / Inkliuzyvna shkola: osoblyvosti orhanizatsii ta upravlinnia : navchalno-metodychnyi posibnyk / Kol. Avtoriv : Kolupaieva A.A., Naida Yu.M., Sofii N.Z. ta in.; [Za red. L.I. Danylenko]. - K., 2007. - 128 s.

Statisticheskie dannyie... - Statisticheskie dannyie na sayte Organizatsii po zaschite prav rebenka [Elektronnyiy resurs]. - Rezhim dostupa : http:///www.opcr/org/english/stats_world.htm.

Pastor, 2009 - Pastor C. Analysing and federation the European assistive technology ICT industry / C. Pastor et al. // European Commission Information Society and Media. - 2009. - 188 p.

Riding, 1991 - Riding R.J. Cognitive style - an overview and integration / R.J. Riding, I. Cheema // Educat. Psychology. - 1991. - V. 11. - P. 193-215.

Rogers, 1993 - Rogers I. The Inclusion Revolution / I. Rogers. - Bloomington : Phi Delton Kappa, 1993. - 258 p.

World Bank, 2007 - World Bank, 2007. Measuring Disability Prevalence [Elektronnyiy resurs] (Raspredelenie urovnya invalidnosti. Vsemirnyiy Bank, 2007). - Rezhim dostupa: http://siteresources. worldbank.org/DISABILITY/Resources/Data/MontPrevalence.pdf.

УДК 392:502.13]:37

Валентина Скутіна, кандидат педагогічних наук, дочент кафедри географії, екології та методики викладання ДВНЗ «ПереяславХмельницький державний педагогічний університет імені Григорія Сковороди».

\section{DOI 10.31470/2308-5126-2019-45-2-108-115}

E-mail: olimp-geograf@ukr.net

ORCID 0000-0001-5023-1665

\section{НАРОДНІ ПРИРОДООХОРОННІ ТРАДИЦІЇ ЯК СИСТЕМНЕ ПЕДАГОГІЧНЕ ЯВИЩЕ}

У статті проаналізовано народні природоохоронні традииії як системне педагогічне явище. Обтрунтовано, що історична стійкість етносу забезпечила постійність його взаємодї з природним середовищем, в ході якої природоохоронні традиції зафіксували найбільш характерні значимі риси локальних екологічних систем, головні їх природні компоненти.

Доведено, щуо основою формування народних природоохоронних традицій є духовний характер взаємодї народу з навколишнім природним середовищем, який сформувався протягом більш ніж тисячолітнього періоду під впливом християнського світогляду.

3'ясовано системність народних природоохоронних традицій з точки зору їх функціональності та змістовності. Обтрунтовано, щзо системність народної традииії дбайливого ставлення до природного середовища зумовлена природними факторами. Цей висновок зроблений на основі того, що історична стійкість етносу забезпечила постійність його взаємодії з географічним середовищем.

Ключові слова: традииї, звичаї, народні природоохоронні традиції, народні традиції природоохоронного виховання.

The article analyzes the national nature traditions as a systemic pedagogical phenomenon. It is grounded that the historical stability of the ethnos ensured the continuity of its interaction with the natural environment, during which the nature traditions recorded the most characteristic features of local ecological systems, their main natural components.

It is proved that the basis of the formation of folk nature conservation traditions is the spiritual nature of the interaction of the people with the natural environment, which was formed during more than a thousand years under the influence of the Christian world outlook.

The systematic nature of folk nature conservation traditions is determined from the point of view of their functionality and content.

It is substantiated that the system of folk tradition of careful attitude to the natural environment is due to natural factors. This conclusion is based on the fact that the historical stability of the ethnic group ensured the continuity of its interaction with the geographical environment. During this long interaction traditions recorded the 